\title{
Lung Cancer in a Male Smoker Treated by Adjunct Nutritional and Phyto-Therapy
}

\author{
Steve Yap*
}

DSY Wellness and Longevity Center, Kuala Lumpur, Malaysia

\begin{abstract}
Current understanding of the aetiology of lung cancer suggests that oxidative stress is strongly implicated in its pathogenesis with both internal cellular production of free radicals and external carcinogens such as from tobacco smoke. Other risk factors include family history, exposure to radiation, chronic obstructive pulmonary disease, overweight, chronic inflammation, and poor dietary habits. Patients' survival rates have not changed appreciably suggesting that Western conventional therapeutic advances have been rather slow. This case study shows how a welldesigned nutritional and phyto-therapy may offer an effective adjunct treatment for non-small cell lung cancer (NSCLC). The protocol included dietary and lifestyle modifications as well as the use of evidence-based nutraceuticals and herbs. The terminal cancer patient in question was diagnosed by his oncologist as being cancer-free after five months or so. According to ANMP (www.anmp.org.my), such a protocol treats, controls, and/or prevents chronic metabolic disorders such as cancer by impacting on the patient's physiological, hormonal, and/or immune functions.
\end{abstract}

Keywords: Non-small cell lung cancer, angiogenesis, metastasis, cachexia, anorexia, nutritional therapy, CT scans and chest X-rays, adjunct cancer therapy.

\section{CASE PRESENTATION}

Samuel Q., age 51 and a senior radiology technician employed at a major government hospital, was referred by a family friend to seek 'alternative' or complementary therapy(ies) for his end-stage nonsmall cell lung cancer (NSCLC) after conventional therapy failed to arrest its progression since it was first diagnosed at stage II some four months earlier. He suffered persistent cough, shortness of breath, wheezing and occasional chest pain. He was unclear as to what extent his accumulated occupational hazard and smoking contributed to his conditions. A senior physician at the same hospital had earlier diagnosed him as having bronchitis and alveolitis (inflamed alveoli or air sacs). After taking cough mixtures for two months and not recovering, he had a chest radiograph done which showed some abnormal mass in his lungs. A computerised tomography (CT)-guided biopsy confirmed his worst fear. Within two days he was placed on radiation cum chemotherapy. Although surgery would be a common way to treat adenocarcinoma lung cancer, he was advised otherwise. However, his lung malignancy progressed to the terminal stage after sixteen weeks. Besides reducing the number of cigarette smoked, he was told by his oncologist that he could "eat or drink almost anything" as he pleased. However, his appetite deteriorated within six weeks after he developed anaemia resulting apparently from damage inflicted to

*Address corresponding to this author at the DSY Wellness \& Longevity Center, Kuala Lumpur, Malaysia; Tel: +60342701266; Fax: +60342701831; E-mail: dsy@dsywellness.com his bone marrow by chemotherapy received. His serum ferritin level was significantly elevated as indicated on Table 1. With significant weight loss, he felt rather weak and feared that his cachexia (physical wasting syndrome) might worsen.

The patient had been a smoker for the past twenty years or so. He claimed that long working hours promoted his smoking habit and elevated his mental stress over the past decade when he took on a more senior position at his present hospital. There was no family history of lung cancer. However, he admitted that his dietary habits were far from ideal.

Consequently, the dietary plan recommended included these food items:

(a) Cruciferous vegetables such as cabbages and broccoli as well as bean sprouts: steamed or lightly cooked, served two or more times daily. These may protect against cancer cells proliferation. Generally, the more quality vegetables are consumed by lung cancer patients, the longer they seem to live [1]. There seems to be a significant association between the highest flavonoid intake from vegetables and berries and reduced risk of developing lung cancer [2]. Sulforaphane, an isothiocyanate (sulfur-containing compound) present in some cruciferous vegetables, possesses anticancer properties [3].

(b) Leafy vegetables and plant sterols and sterolins from sources such as rice bran, sesame seeds, sunflower seeds, pumpkin seeds, pearl barley, 
Table 1: Extracts from Serum Test Results for the First Six Months of 2011-2012

\begin{tabular}{|c|c|c|c|c|}
\hline CEA (<5ng/ml) & 121.0 & 71.2 & 25.5 & 5.2 \\
\hline hs-CRP (<1mg/L) & 30.5 & 12.2 & 10.9 & 3.5 \\
\hline $\mathrm{HbA1c}(<5.1 \%)$ & 7.1 & 6.8 & 6.5 & 6.1 \\
\hline Cortisol (50-230ng/ml) & 228 & 205 & 177 & 112 \\
\hline Free T3 (1.6-3.6pg/ml) & 1.8 & 2.1 & 2.2 & 2.5 \\
\hline DHEA-S (0.32-3.80ug/ml) & 0.49 & 0.87 & 1.12 & 1.45 \\
\hline Haemoglobin $(>12.5 \mathrm{~g} / \mathrm{dl})$ & 9.3 & 10.6 & 11.5 & 11.9 \\
\hline$(25(\mathrm{OH}) \mathrm{D}(>30 \mathrm{ng} / \mathrm{mL})$ & 15 & 31 & 52 & 67 \\
\hline
\end{tabular}

soy beans, and soy products: lightly cooked, two or more servings daily. There is growing epidemiologic evidence that increased intake of phytoestrogens are associated with decreased risk of lung cancer [4]. Fresh orange-yellow corn is a rich source of lutein [5], which protects against lung cancer [6]. Green leafy vegetables are rich in folate, which deficiency could predispose individuals toward developing lung cancer [7].

(c) Pumpkin and carrot: steamed or lightly cooked, two or more servings daily. These are some of the richest source of alpha carotene, which protects against lung cancer. Extensive studies confirm free radicals are involved in the initiation and promotion of cancer [8-10]. Consequently, low plasma levels of dietary antioxidants are correlated with increased cancer mortality rates $[11,12]$. Lung cancer risk can be significantly lowered in patients who consumed a diet high in a variety of carotenoids [13].

(d) Red tomatoes or tomato paste added to cooking or soup daily. A diet high in tomatoes may reduce overall incidence of cancer by some $50 \%$ [14] including cancer of the lung [13]. Furthermore, the flavonoid lycopene can double the protective capacity of carotene [15].

(e) Spices added to daily cooking. Onions contains quercetin, which like antiestrogen drug tamoxifen has similar affinity to type II estrogen binding sites in NSCLC cell lines and hence it could regulate their growth [16]. Turmeric contains curcumin, which is able to positively affect gene transcription and to induce cancer cell apoptosis (programmed cell death) [17].

(f) Nuts: raw or lightly cooked, served two or more times per day. Brazil nuts are very rich source of selenium, which deficiency increases the risk of fatal cancer [18]. However, due to its possible toxicity at very high dosage [19], a food source for this micro-nutrient is recommended. Selenium could offer a $50 \%$ reduction in overall cancer death rate [20] and could decrease lung cancer risk by up to $50 \%$ [21]. Just two quality Brazil nuts daily provide some $200 \mathrm{mcg}$ selenium sufficient to effect this risk major reduction [22]. A higher dietary intake of d-alpha-tocopherol and other mixed tocopherols such as from raw nuts and seeds could also cut the risk of lung cancer by $55 \%$ [23] and this vitamin is especially protective for smokers [24].

(g) Fresh organic berries and fruits such as blueberry, kiwi, bell pepper and guava: two or more servings daily. These are some of the richest sources of ascorbic acid, which is negatively associated with most cancers [25].

(h) Fish such as mackerel, wild salmon, cod, or anchovy: steamed and served daily. These fatty seafood are rich in omega-3 fats needed to reverse cachexia by inhibiting LMF (lipid 
mobilizing factor) produced by the developing tumour, which causes direct breakdown of the patient's adipose (fat) tissues [26].

(i) Food rich in L-tryptophan such as soy isolate, organic lean poultry, leafy vegetables, legumes, and seeds: lightly cooked and served two or more times per day. This essential amino acid is a precursor to the neurotransmitter serotonin, which is then converted to the neurohormone melatonin [27], which can enhance the patient's survival [28].

The beverages recommended were:

(a) Yellow (Chinese) or Green (Japanese tea: three to four cups a day after meal. This beverage could prevent further development of tumours by blocking angiogenesis (growth of new blood vessels) [29]. It has chemo-preventive properties and it may reduce the dosage of chemotherapy drugs used by enhancing their cytotoxicity [30]. These teas could also block or reduce absorption of iron from food.

(b) Malaysian cocoa, low fat, powdered: two or more cups a day. This beverage has as much or higher level of antioxidants than tea or red wine [31] useful for lowering oxidative stress.

The patient was advised to drastically reduce or avoid these food items:

(i) Red meat and processed meat such as burgers, sausages, and canned meat. Intake of these meat sources may be positively associated with lung cancer, with individuals in the highest quintile of processed meat intake having a $16 \%$ elevated risk for lung cancer [32]. Besides being a generator of damaging free radicals and lipid peroxidation, excess iron from these meat sources promotes malignant cell DNA (deoxyribonucleic acid) replication.

(ii) Bottled omega-6 polyunsaturated fatty acids such as those from corn oil, sunflower oil, safflower oil, and soy oil since these are easily oxidised as well as being used by the body to produce arachidonic acid and pro-inflammatory prostaglandins leading to accelerated tumour growth [33] or carcinogen-induced, precancerous lesions [34]. However, our body needs small quantity of non-oxidised omega- 6 for it to function efficiently. (iii) Refined sugars, soft drinks, fruit drinks, packaged fruit juices and refined carbohydrates such as toasted cereals, bread, instant breakfast cereals, tidbits, biscuits and noodles. Cancer or tumour cells are primarily sugar metabolisers [35] in an anaerobic environment. Hyperglycemia also increases the pro-inflammatory process and it adversely affects the patient's immune system [36].

The phyto-extracts prescribed for this patient were:

(a) Astragalus membranaceus extract (standardised to $15 \%$ astragaloids): one gram three times a day. This root extract has immunologic benefits by stimulating macrophage and natural killer cell activity and inhibiting T-helper cell type-2 cytokines. It combines well with chemotherapy to enhance its effectiveness [37]. Astragaloids stimulate immuno-competent cells and can, depending on dosage used, reduce side effects in patients on chemotherapy [38].

(b) Artemisia annua herbal tea: 4 cups a day. This widely-grown Tropical herb could be used together with elevated levels of transferrin in drug-resistant lung cancer [39]. Its active components such as triterpene and sesquiterpene are able to destroy cells in NSCLC [40]. When taken in sufficient dosages, their effectiveness may be comparable with other standard chemotherapy drugs used to combat cancer but with the distinct advantage of rather low toxicity [41].

These nutrients were prescribed to be taken with meals containing some fats/cooking oil:

(1) Co-enzymeQ10 (ubiquinone): $100 \mathrm{mg}$ three times a day since its levels tend to be significantly lower in patients suffering from cancers [42- 44].

(2) Malaysian wild pollens: one teaspoon three a day. This supplementation is a rich source of multivitamins/minerals/ antioxidants/enzymes, which intake is associated with improved survival and quality of life in NSCLC patients [45]. In addition, NSCLC patients who take quality vitamin supplements and/or with higher circulating blood folate concentrations are more likely to be long-term survivors [46].

(3) Soy isoflavones (standardised to $25 \%$ genistein): $500 \mathrm{mg}$ three a day. Phyto-nutrient such as 
genistein may reverse radio-resistance and chemo-resistance in cancer cells [47]. It induces apoptosis in NSCLC cells through a gene p53independent pathway and, thus, acts as an anticancer agent [48]. Genistein in isoflavones antagonises estrogen-and androgen-mediated signaling pathways in the processes of carcinogenesis [47]. Furthermore, it has antioxidant properties and is a potent inhibitor of angiogenesis and metastasis [49]. Antiangiogenic therapy is a useful weapon in the treatment of solid tumours, including non-small cell lung cancer [50].

(4) Curcuma longa extract (standardised to $90 \%$ curcumin with $2.5 \%$ pepper oil): $1.5 \mathrm{~g}$ three times a day can inhibit cancer at its initiation, promotion and progression stages of development [51]. It is a cyclooxygenase-2 (COX2)-inhibitor and it possesses both antiinflammatory and antioxidant properties [52]. It may substantially enhance chemotherapy drug Vinorelbine-mediated apoptosis in lung cancer cells [53].

Quercetin/bromelain 3:1: one gram three times a day to help inhibit cell proliferation and may induce apoptosis via caspase- 3 cascade in the human lung cancer [54].

Red grapes extracts [standardised to 50\% resveratrol (3,5,4'-trihydroxy-trans-stilbene)]: $500 \mathrm{mg}$ three times a day could enhance cell killing by conventional cancer treatment, with a sensitiser enhancement ratio of up to 2.2. Resveratrol enhances the radiosensitivity of lung cells by inhibiting the DNA transcription factor NF-kappaB [55]. This antioxidant is known to interfere with all three stages of carcinogenesis. It also possesses anti-angiogenic properties [56] and enhances functions of cellular mitochondria [57] for improved energy production.

Shark cartilage (powdered, hydrosoluble): two grams in gel capsules three times a day could slow or inhibit growth of tumors through antiangiogenesis [58-61] with little or no toxicity. The link between angiogenesis and tumour progression is strong [62]. Bioavailable shark cartilage can inhibit proliferation of blood capillaries induced by tumours $[63,64]$.

(8) Vitamin D: 4,000IU twice times a day. Its mechanisms of action include inhibition of cell proliferation, stimulation of apoptosis, suppression of inflammation, and inhibition of tumour angiogenesis, invasion, and metastasis [65].

(9) Ultra Refined Anchovy Fish Oil [Eicosapentaenoic acid (EPA) 500mg: docosahexaenoic acid (DHA) 200mg]: one gram gel capsule three times a day. This supplement may result in increased chemotherapy efficacy without affecting the toxicity profile and may contribute to increased patient survival [66]. Fish oil can improve the quality of life parameters in patients with NSCLC [67] and it is negatively associated with lung cancer [68]. Its EPA interferes with multiple mechanisms implicated in the pathogenesis of cachexia [69].

\section{PATHOGENESIS}

Cancer is characterised by uncontrolled cell growth that may consume the patient through malnutrition, organ failure or infection which it is capable of inflicting. NSCLC is an adenocarcinoma of the glandular tissue that begins in the cells that line the alveoli and produce substances such as mucus. It accounts for more than $80 \%$ of all lung cancer cases [70] with overall 5-year survival rate of just $16 \%$ [71]. While persistent cough and shortness of breath are common signs of NSCLC, the presence of chronic obstructive pulmonary disease can raise risk of lung cancer by up to $450 \%$ [72].

Cigarette smoke generates significant amount of oxidative stress and is widely viewed as the principal risk factor for the development of lung cancer [73-75] accounting for up to $90 \%$ of lung cancer incidence [76] since cigarette smoke contains more than 60 known carcinogens [77]. While some researchers claim that in the absence of cigarette smoking lung cancer would be a rare disease [78], about $50 \%$ of all women with lung cancer worldwide are non-smokers [79]. Perhaps, their higher body mass index raises their risk of malignancies [80]. The neoplastic process is also associated with inflammation [81] and occupational exposure to arsenic [82].

Second-hand smoke may cause lung cancer in lifelong non-smokers. Risk increases with the amount and duration of tobacco inhaled. Similar to many other cancers, lung cancer is initiated by activation of oncogenes or inactivation of tumour suppressor genes [83]. There may be significant associations between Cytochrome P450 1A1 gene polymorphisms (CYP1A1) 
and lung cancer $[84,85]$, while some studies found no significant associations [86]. However, lung cancer seems to be more strongly associated with Cytochrome P450 1B1 gene polymorphisms (CYP1B1) [87, 88]. Several other genetic polymorphisms are associated with lung cancer such as genes coding for interleukin-1 [89], apoptosis promoters such as caspase-8 [90], and DNA repair molecules such as XRCC1 [91]. People with these polymorphisms may be more likely to develop lung cancer after exposure to carcinogens.

Dietary factors have been proposed as potential risk modulators, with antioxidants vitamins $\mathrm{A}, \mathrm{C}$ and $\mathrm{E}$ as having a protective effect [92]. Indeed, between $50 \%$ and $90 \%$ of all cancers could be prevented with skilfully and individually designed nutrition [93]. Many cancer patients die from malnutrition and/or infections both of which are linked to improper nutrition. Change in nutritional status is significantly associated with change in quality of life and change in lean body mass [94]. Cachexia not only shortens survival rates in patients, but also any positive response to chemotherapy is significantly reduced [66]. Even gradual weight loss has been identified as an indicator of poor prognosis in cancer patients [95]. Unfortunately, some $60 \%$ of lung cancer patients have already experienced a significant weight loss at time of their first diagnosis [96], defined as at least a $10 \%$ loss of body weight over a six months' period [97]. Proper nutritional therapy helps cancer patients maintain their appropriate body weight and nutrition stores while offering improved quality of life [98]. However, there may be other physiological issues affecting patient's nutritional status such as indigestion, hypometabolism, food malabsorption and obstructions [99].

Unfortunately, even with the best supportive care alone, patients with metastatic NSCLC have a median survival period of just 4 to 5 months and a one-year survival rate of approximately $10 \%$ [100]. Over the past two decades, chemotherapy for NSCLC has raised average survival of patients by just two months [101]. A recent study showed only $1.5 \%$ of Australian patients with NSCLC benefited from chemotherapy [102]. The need for an integrative therapy is evident.

\section{SCREENING PITFALLS}

Computed tomography (CT) scans and chest X-rays have been promoted for lung cancer screening, but studies have yet to show if such screening saves lives since they can be associated with significant falsepositive rates [103]. Current evidence does not seem to support lung cancer screening using chest radiography, sputum cytology, or even low-dose CT as studies investigating the application of these screening techniques have not reported improved survival benefits [104].

The exhaled breath analysis may be a promising tool [105]. It is a non-invasive approach for the detection of biomarkers associated with oxidative stress in the respiratory tract and has previously being shown to measure differences in levels of oxidative stress or inflammatory markers in patients with various respiratory conditions such as asthma, chronic obstructive pulmonary disease and bronchiectasis $[106,107]$.

Efforts are in progress to develop more noninvasive diagnostics for lung cancer using techniques such as detection of methylated tumour DNA in sputum, serum proteomics, mRNA or microRNA (endogenous RNAs involved in regulating gene expression) profiling in peripheral blood, and exhaled volatile markers [108]. Although each of these approaches has its own merits, none has yet passed the exploratory stage [109].

\section{CASE DIAGNOSIS}

Besides comprehensive history taking, diagnosis was greatly facilitated by the numerous test reports which the patient regularly sent in for review. Although in many similarly advanced NSCLC cases, chemotherapy seems to improve survival and is therefore widely used as first-line treatment [110], the patient in question seemed rather unwell for any further treatment using this approach. Indeed, he was advised by the hospital oncologist that he was free to use any other treatment option. Periodic blood tests showed an anaemic state and progressively elevated serum ferritin levels while his tumour protein markers $\mathrm{CA}-125$ and CEA (Carcino-embryonic Antigen) levels rising rapidly over the past eight weeks or so. These are considered useful clinical markers for monitoring therapeutic outcome [111].

The high fatality is linked partly to the fact that the majority of the lung cancers are diagnosed at their late stages with the conventional treatment outcome being suboptimal [112]. Close to $70 \%$ of lung cancer patients present with locally advanced or metastatic disease at the time of their diagnosis [113].

The patient showed signs of cachexia, which was manifested as weight loss with significant depletion of 
both his adipose tissue and lean muscle mass. This condition alone is estimated to be the immediate cause of death in up to $40 \%$ of cancer patients [114].

A major obstacle to this nutritional therapy is anorexia (loss of appetite or desire to eat), which the patient claimed was the result of his chemotherapy. This condition is a most common side-effect in individuals with widely metastatic disease [115] because of physiologic alterations in metabolism during carcinogenesis. It tends to hasten the course of cachexia [96].

The patient's tumour/cancer and inflammatory markers improved significantly, so was his diabetes, serum ferritin levels, and anaemia. The Oncologist's Report issued by the hospital dated May 19, 2012 indicated tumour remission to stage 1 and absence of malignancy. The patient continued with the recommended nutritional therapy, which outcome thus far suggested an effective adjunct therapy to initiate NSCLC remission. It was, however, uncertain if this natural therapy would achieve similar results for other terminal lung cancer patients. A large cohort of patients with similar conditions has to be studied to throw more light on the merits of offering this adjunct therapy on a wider scale.

\section{REFERENCES}

[1] Goodman M. Vegetable consumption in lung cancer longevity. Eur J Cancer 1992; 28: 495-9. http://dx.doi.org/10.1016/S0959-8049(05)80086-3

Tang NP, Zhou B, Wang B, Yu RB, Ma J. Flavonoids intake and risk of lung cancer: a meta-analysis. Jpn J Clin Oncol 2009; 39: 352-9.

http://dx.doi.org/10.1093/jijco/hyp028

[3] Gaby A. Nutritional Medicine. Fritz Perlbery Publishing. Concord NH: 2011; P1212.

[4] Schabath MB, Hernandez LM, Wu X, Pillow PC, Spitz MR. Dietary phytoestrogens and lung cancer risk. JAMA 2005; 294: 1493-504.

http://dx.doi.org/10.1001/jama.294.12.1493

[5] Sommerburg O, Keunen JE, Bird AC, van Kuijk FJ. Fruits and vegetables that are sources for lutein and zeaxanthin: the macular pigment in human eyes. $\mathrm{Br} \mathrm{J}$ Ophthalmol 1998; 82: $907-10$

http://dx.doi.org/10.1136/bjo.82.8.907

[6] Pung A, Rundhaug JE, Yoshizawa CN, Bertram JS. Beta carotene and canthaxanthin inhibit chemically and physically induced neoplastic transformation in 10T1/2 cells. Carcinogenesis 1988; 9: 1533-9.

http://dx.doi.org/10.1093/carcin/9.9.1533

[7] Heimburger D. Localized deficiencies of folic acid in aerodigestive tissues. Ann NY Acad Sci 1992; 669: 87-96. http://dx.doi.org/10.1111/j.1749-6632.1992.tb17091.x

[8] Sun Y. Free radicals, antioxidant enzymes, and carcinogenesis. Free Radic Biol Med 1990; 8: 583-99. http://dx.doi.org/10.1016/0891-5849(90)90156-D
[9] Borek C. Free-radical processes in multistage carcinogenesis. Free Radic Res Commun 1991; 12-13(Pt 2): 745-50.

http://dx.doi.org/10.3109/10715769109145854

[10] Florence TM. The role of free radicals in disease. Aust NZ J Ophthalmol 1995; 23: 3-7.

http://dx.doi.org/10.1111/j.1442-9071.1995.tb01638.x

[11] Chen J, Geissler C, Parpia B, Li J, Campbell TC. Antioxidant status and cancer mortality in China. Int J Epidemiol 1992; 21: $625-35$

http://dx.doi.org/10.1093/ije/21.4.625

[12] Stahelin HB, Gey KF, Eichholzer M, Lüdin E, Bernasconi F, et al. Plasma antioxidant vitamins and subsequent cancer mortality in the 12-year follow-up of the prospective Basel Study. Am J Epidemiol 1991; 133: 766-75.

[13] Michaud DS, Feskanich D, Rimm EB, Colditz GA, Speizer $\mathrm{FE}$, et al. Intake of specific carotenoids and risk of lung cancer in 2 prospective US cohorts. Am J Clin Nutr 2000; 72 : 990-7.

[14] Franceschi S, Bidoli E, La Vecchia C, Talamini R, D’Avanzo $\mathrm{B}$, et al. Tomatoes and risk of digestive-tract cancers. Int $\mathrm{J}$ Cancer 1994; 59: 181-4.

http://dx.doi.org/10.1002/ijc.2910590207

[15] Di Mascio P, Kaiser S, Sies H. Lycopene as the most efficient biological carotenoid singlet oxygen quencher. Arch Biochem Biophys 1989; 274: 532-8. http://dx.doi.org/10.1016/0003-9861(89)90467-0

[16] Caltagirone S, Ranelletti FO, Rinelli A, Maggiano N, Colasante A, et al. Interaction with type II estrogen binding sites and antiproliferative activity of tamoxifen and quercetin in human non-small-cell lung cancer. Am J Respir Cell Mol Biol 1997; 17: 51-9.

[17] Sharma RA, Gescher AJ, Steward WP. Curcumin: the story so far. Eur J Cancer 2005; 41: 1955-68.

http://dx.doi.org/10.1016/i.ejca.2005.05.009

[18] Salonen JT, Salonen R, Lappetelainen R, Maenpaa PH, Alfthan $G$, et al. Risk of cancer in relation to serum concentrations of selenium and vitamins $A$ and $E$ : matched case-control analysis of prospective data. Br Med J 1985 290: 417-20.

http://dx.doi.org/10.1136/bmi.290.6466.417

[19] Omenn GS. Micronutirents (vitamins and minerals) as cancer-preventive agents. IARC Sci Publ 1996; 139: 33-45.

[20] Clark LC, Combs GF Jr, Turnbull BW, Slate EH, Chalker DK, et al. Effects of selenium supplementation for cancer prevention in patients with carcinoma of the skin: a randomized controlled trial. Nutritional Prevention of Cancer Study. JAMA 1996; 276: 1957-63.

http://dx.doi.org/10.1001/jama.1996.03540240035027

[21] National Research Council Staff. Diet and Health: Implications for Reducing Chronic Disease Risk. Washington, DC: National Academy of Education 1989; pp. 376-9.

[22] Schrauzer $G$. The nutritional significance, metabolism and toxicology of selenomethionine. Adv Food Nutr Res 2003: 47: 73-112.

http://dx.doi.org/10.1016/S1043-4526(03)47002-2

[23] Mahabir S, Schendel K, Dong YQ, Barrera SL, Spitz MR, et al. Dietary alpha- beta- gamma and delta-tocopherols in lung cancer risk. Int J Cancer 2008; 123: 1173-80. http://dx.doi.org/10.1002/ijc.23649

[24] Woodson K, Tangrea JA, Barrett MJ, Virtamo J, Taylor PR, et al. Serum alpha-tocopherol and subsequent risk of lung cancer among male smokers. J Natl Cancer Inst 1999; 91 : 1738-43. http://dx.doi.org/10.1093/inci/91.20.1738

[25] Chen J, Geissler C, Parpia B, Li J, Campbell TC. Antioxidant status and cancer mortality in China. Int J Epidemiol 1992; 21: $625-5$.

http://dx.doi.org/10.1093/ije/21.4.625 
[26] Tisdale MJ. Cancer cachexia. Anticancer Drugs 1993; 4: 1525.

http://dx.doi.org/10.1097/00001813-199304000-00001

[27] Wurtman RJ, Anton-Tay F. The mammalian pineal as a neuroendocrine transducer. Recent Prog Horm Res 1969; 25: 493-522

[28] Lissoni P, Chilelli M, Villa S, Cerizza L, Tancini G. Five-years survival in metastatic non-small lung cancer patients treated with chemotherapy alone or chemotherapy and melatonin: a randomized trial. J Pineal Res 2003; 35: 12-15. http://dx.doi.org/10.1034/j.1600-079X.2003.00032.x

[29] Cao Y, Cao R. Angiogenesis inhibited by drinking tea. Nature 1999; 398: 381. http://dx.doi.org/10.1038/18793

[30] Laurie SA, Miller VA, Grant SC, Kris MG, Ng KK. Phase I study of green tea extract in patients with advanced lung cancer. Cancer Chemother Pharmacol 2005; 55: 33-8. http://dx.doi.org/10.1007/s00280-004-0859-1

[31] Lee KW, Kim YJ, Lee HJ, Lee CY. Cocoa Has More Phenolic Phytochemicals and a Higher Antioxidant Capacity than Teas and Red Wine. J Agr Food Chem 2003; 51(25): 7292-7295. http://dx.doi.org/10.1021/jf0344385

[32] Cross AJ, Leitzmann MF, Gail MH, Hollenbeck AR, Schatzkin A, Sinha R. A prospective study of red and processed meat intake in relation to cancer risk. PloS Med 2007; 4: e325. http://dx.doi.org/10.1371/journal.pmed.0040325

[33] Wallace FA, Neely SJ, Miles EA, Calder PC. Dietary fats affect macrophage-mediated cytotoxicity towards tumour cells. Immunol Cell Biol 2000; 78: 40-8.

http://dx.doi.org/10.1046/j.1440-1711.2000.00867.x

[34] Roebuck BD. Dietary fat and the development of pancreatic cancer. Lipids 1992; 27 : 804-6.

http://dx.doi.org/10.1007/BF02535854

[35] Rothkopf M. Fuel utilization in neoplastic disease: implications for the use of nutritional support in cancer patients. Nutr Supp 1990; 6: 14-16.

[36] Collier B, Dossett LA, May AK, Diaz JJ. Glucose Control and the Inflammatory Response. Nutr Clin Pract 2008; 23: 3-15. http://dx.doi.org/10.1177/011542650802300103

[37] McCulloch M, See C, Shu XJ, Broffman M, Kramer A, et al. Astragalus-based Chinese herbs and platinum-based chemotherapy for advanced non-small-cell lung cancer: meta-analysis of randomized trials. J Clin Oncol 2006; 24: 419-30.

http://dx.doi.org/10.1200/JC0.2005.03.6392

[38] Taixiang W, Munro AJ, Guanjian L. Chinese medical herbs for chemotherapy side effects in colorectal cancer patients. Cochrane Database Syst Rev 2005; 1: CD4540.

[39] Sadava D, Phillips T, Lin C, Kane SE. Transferrin overcomes drug resistance to artemisinin in human small cell lung carcinoma cells. Cancer Lett 2002; 179: 151-156. http://dx.doi.org/10.1016/S0304-3835(02)00005-8

[40] Kwon, Phytochemical constituents of Artemisia stolonifera. Arch Pharm Res 2001; 24: 312-5. http://dx.doi.org/10.1007/BF02975098

[41] Efferth T, Dunstan H, Sauerbrey A, Miyachi H, Chitambar CR. The anti-malarial artesunate is also active against cancer. Int J Oncol 2001; 18: 767-73.

[42] Chipperfield B, Chipperfield J. Ubiquinone and nucleic acid concentrations in the heart muscle of cancer patients and normal controls. Clin Chim Acta 1971; 31: 459-65. http://dx.doi.org/10.1016/0009-8981(71)90419-0

[43] Weber C, Sejersgard-Jakobsen T, Mortensen SA, Paulsen G, Holmer G. Antioxidative effect of dietary coenzyme Q10 in human blood plasma. Int J Vit Nutr Res 1994; 64: 311-5.

[44] Folkers K, Osterborg A, Nylander M, Morita M, Mellstedt H. Activities of vitamin Q10 in animal models and a serious deficiency in patients with cancer. Biochem Biophys Res Commun 1997; 234: 296-9.

http://dx.doi.org/10.1006/bbrc.1997.6522

[45] Jatoi A, Williams B, Nichols F, Marks R, Aubry MC, et al. Is voluntary vitamin and mineral supplementation associated with better outcome in non-small cell lung cancer patients? Results from the Mayo Clinic lung cancer cohort. Lung Cancer 2005; 49: 77-84. http://dx.doi.org/10.1016/j.lungcan.2005.01.004

[46] Jatoi A, Daly BD, Kramer G, Mason JB. A cross-sectional study of vitamin intake in postoperative non-small cell lung cancer patients. J Surg Oncol 1998; 68: 231-6. http://dx.doi.org/10.1002/(SICl)10969098(199808)68:4<231::AID-JSO5>3.0.CO;2-5

[47] Banerjee S, Li Y, Wang Z, Sarkar FH. Multi-targeted therapy of cancer by genistein. Cancer Lett 2008; 269: 226-42. http://dx.doi.org/10.1016/j.canlet.2008.03.052

[48] Lian F, Li Y, Bhuiyan M, Sarkar FH. P53-independent apoptosis induced by genistein in lung cancer cells. Nutr Cancer 1999; 33: 125-31. http://dx.doi.org/10.1207/S15327914NC330202

[49] Sarkar F, Li Y. Soy isoflavones and cancer prevention. Cancer Invest 2003; 21: 744-57. http://dx.doi.org/10.1081/CNV-120023773

[50] Vokes E, Herbst R, Sandler A. Angiogenesis inhibition in the treatment of lung cancer. Clin Adv Hematol Oncol 2006; 4: 110.

[51] Nagabhushan M, Bhide S. Curcumin as an inhibitor of cancer. J Am Coll Nutr 1992; 11: 192-8.

[52] Bengmark S. Curcumin, an atoxic antioxidant and natural NfkappaB, cyclooxygenase-2, lipooxygenase, and inducible nitric oxide synthase inhibitor: a shield against acute and chronic diseases. JPEN J Parenter Enteral Nutr 2006; 30: 45-51.

http://dx.doi.org/10.1177/014860710603000145

[53] Sen S, Sharma H, Singh N. Curcumin enhances Vinorelbine mediated apoptosis in NSCLC cells by the mitochondrial pathway. Biochem Biophys Res Commun 2005; 17; 331: 1245-52.

http://dx.doi.org/10.1016/j.bbrc.2005.04.044

[54] Yang JH, Hsia TC, Kuo HM, Chao PD, Chou CC, et al. Inhibition of lung cancer cell growth by quercetin glucuronides via G2/M arrest and induction of apoptosis. Drug Metab Dispos 2006; 34: 296-304. http://dx.doi.org/10.1124/dmd.105.005280

[55] Liao HF, Kuo CD, Yang YC, Lin CP, Tai HC, et al Resveratrol enhances radiosensitivity of human non-small cell lung cancer $\mathrm{NCl}-\mathrm{H} 838$ cells accompanied by inhibition of nuclear factor-kappa B activation. J Radiat Res 2005; 46: 387-93.

http://dx.doi.org/10.1269/jrr.46.387

[56] Cao Y, Fu ZD, Wang F, Liu HY, Han R. Anti-angiogenic activity of resveratrol, a natural compound from medicinal plants. J Asian Nat Prod Res 2005; 7: 205-13. http://dx.doi.org/10.1080/10286020410001690190

[57] Lagouge M, Argmann C, Gerhart-Hines Z, Meziane H, Lerin $C$, Daussin F, et al. Resveratrol improves mitochondrial function and protects against metabolic disease by activating SIRT1 and PGC-1alpha. Cell 2006; 127: 1109-22. http://dx.doi.org/10.1016/j.cell.2006.11.013

[58] Folkman J. Tumor angiogenesis: therapeutic implications. N Eng J Med 1971; 285: 1182-86.

http://dx.doi.org/10.1056/NEJM197111182852108

[59] Lee A, Langer R. Shark cartilage contains inhibitors of tumor angiogenesis. Science 1983; 221: 1185-87. http://dx.doi.org/10.1126/science.6193581 
[60] Moses MA, Sudhalter J, Langer R. Identification of an Inhibitor of Neovascularization from Cartilage. Science 1990; 248: $1408-10$.

http://dx.doi.org/10.1126/science. 1694043

[61] Oikawa T, Ashino-Fuse H, Shimamura M, Koide U, Iwaguchi T. A novel angiogenic inhibitor derived from Japanese shark cartilage. Extraction and estimation of inhibitory activities toward tumor and embryonic angiogenesis. Cancer Lett 1990; 51: 181-5.

http://dx.doi.org/10.1016/0304-3835(90)90100-C

[62] Weidner N, Semple JP, Welch WR, Folkman J. Tumor Angiogenesis and Metastasis - Correlation in Invasive Breast Carcinoma, N Eng J Med 1991; 324: 1-8. http://dx.doi.org/10.1056/NEJM199101033240101

[63] Brem H, Folkman J. Inhibition of tumor angiogenesis mediated by cartilage. J Exp Med 1975; 141: 427-39. http://dx.doi.org/10.1084/jem.141.2.427

[64] Gingras D, Renaud A, Mousseau N, Beliveau R. Shark cartilage as antiangiogenic agent: smart dinks or bitter pills? Cancer Metastasis Rev 2000; 19: 83-6. http://dx.doi.org/10.1023/A:1026504500555

[65] Krishnan AV, Trump DL, Johnson CS, Feldman D. The role of Vitamin D in cancer prevention and treatment. Endocrinol Metabol Clin N Am 2010; 39: 401-418.

http://dx.doi.org/10.1016/j.ecl.2010.02.011

[66] Murphy RA, Mourtzakis M, Chu QS, Baracos VE, Reiman T, Mazurak VC. Supplementation with fish oil increases first-line chemotherapy efficacy in patients with advanced nonsmall cell lung cancer. Cancer 2011; 117: 3774-80. http://dx.doi.org/10.1002/cncr.25933

[67] van der Meij BS, Langius JA, Spreeuwenberg MD, Slootmaker SM, Paul MA, et al. Oral nutritional supplements containing $n-3$ polyunsaturated fatty acids affect quality of life and functional status in lung cancer patients during multimodality treatment: an RCT. Eur J Clin Nutr 2012; 66: 399-404. http://dx.doi.org/10.1038/ejcn.2011.214

[68] Hursting SD, Thornquist M, Henderson MM. Types of dietary fat and the incidence of cancer at five sites. Prev Med 1990; 19: 242-53.

http://dx.doi.org/10.1016/0091-7435(90)90025-F

[69] Argilés JM. Cancer-associated malnutrition. Eur J Oncol Nurs 2005; 9(Suppl 2): S39-50.

http://dx.doi.org/10.1016/j.ejon.2005.09.006

[70] Travis WD, Travis LB, Devesa S. Lung cancer. Cancer 1995; 75: 191-202.

http://dx.doi.org/10.1002/1097-

0142(19950101)75:1+<191::AID-

CNCR2820751307>3.0.CO;2-Y

[71] Jemal A, Siegel R, Ward E, Hao Y, Xu J, et al. Cancer statistics, 2009. CA Cancer J Clin 2009; 59: 225-49. http://dx.doi.org/10.3322/caac.20006

[72] Punturieri A, Szabo E, Croxton TL, Shapiro SD, Dubinett SM. Lung cancer and chronic obstructive pulmonary disease: needs and opportunities for integrated research. J Natl Cancer Inst 2009; 101: 554-9.

http://dx.doi.org/10.1093/jnci/djp023

[73] Hecht S. Cigarette smoking and lung cancer: chemical mechanisms and approaches to prevention. Lancet Oncol 2002; 3: 461-9.

http://dx.doi.org/10.1016/S1470-2045(02)00815-X

[74] Knaapen AM, Gungor N, Schins RP, Borm PJ, Van Schooten FJ. Neutrophils and respiratory tract DNA damage and mutagenesis: a review. Mutagenesis 2006; 21: 225-36. http://dx.doi.org/10.1093/mutage/gel032

[75] Rahman I, Biswas SK, Kode A. Oxidant and antioxidant balance in the airways and airway diseases. Eur $J$ Pharmacol 2006; 533: 222-39.

http://dx.doi.org/10.1016/j.ejphar.2005.12.087
[76] Biesalski HK, Bueno de Mesquita B, Chesson A, Chytil F, Grimble R, et al. European Consensus Statement on Lung Cancer: risk factors and prevention. Lung Cancer Panel. CA Cancer J Clin 1998; 48: 167-76.

http://dx.doi.org/10.3322/canjclin.48.3.167

[77] Hecht S. Tobacco carcinogens, their biomarkers and tobacco-induced cancer. Nat Rev Cancer 2003; 3: 733-44. http://dx.doi.org/10.1038/nrc1190

[78] Alberg A, Nonemaker J. Who is at high risk for lung cancer? Population-level and individual-level perspectives. Semin Respir Crit Care Med 2008: 29: 223-32. http://dx.doi.org/10.1055/s-2008-1076742

[79] Marquez-Garban DC, Mah V, Alavi M, Maresh EL, Chen HW, et al. Progesterone and estrogen receptor expression and activity in human non-small cell lung cancer. Steroids 2011; 76: 910-20.

[80] Renehan AG, Tyson M, Egger M, Heller RF, Zwahlen M. Body-mass index and incidence of cancer: a systematic review and meta-analysis of prospective observational studies. Lancet 2008; 371: 569-78. http://dx.doi.org/10.1016/S0140-6736(08)60269-X

[81] Chan HP, Lewis C, Thomas PS. Oxidative stress and exhaled breath analysis: a promising tool for detection of lung cancer. Cancers 2010; $2: 32-42$.

http://dx.doi.org/10.3390/cancers2010032

[82] Neuberger J, Field R. Occupation and lung cancer in nonsmokers. Rev Environ Health 2003; 18: 251-67. http://dx.doi.org/10.1515/REVEH.2003.18.4.251

[83] Fong KM, Sekido Y, Gazdar AF, Minna JD. Molecular biology of lung cancer: clinical implications. BMJ (Thorax) 2003; 58: 892-900.

[84] Hung RJ, Boffetta P, Brockmoller J, Butkiewicz D, Cascorbi I, et al. CYP1A1 and GSTM1 genetic polymorphisms and lung cancer risk in Caucasian non-smokers: a pooled analysis. Carcinogenesis 2003; 24: 875-82. http://dx.doi.org/10.1093/carcin/bgg026

[85] Ng DP, Tan KW, Zhao B, Seow A. CYP1A1 polymorphisms and risk of lung cancer in non-smoking Chinese women: influence of environmental tobacco smoke exposure and GSTM1/T1 genetic variation. Cancer Causes Contr 2005; 16: 399-405.

\section{http://dx.doi.org/10.1007/s10552-004-5476-0}

[86] Gsur A, Haidinger G, Hollaus P, Herbacek I, Madersbacher $\mathrm{S}$, et al. Genetic polymorpisms of CYP1A1 and GSTM1 and lung cancer risk. Anticancer Res 2001; 21: 2237-42.

[87] Wenzlaff AS, Cote ML, Bock CH, Land SJ, Santer SK, et al. CYP1A1 and CYP1B1 polymorphisms and risk of lung cancer among never smokers: a population-based study. Carcinogenesis 2005; 26: 2207-12. http://dx.doi.org/10.1093/carcin/bgi191

[88] Yang M, Choi Y, Hwangbo B, Lee JS. Combined effects of genetic polymorphisms in six selected genes on lung cancer susceptibility. Lung Cancer 2007; 57: 135-42.

http://dx.doi.org/10.1016/j.lungcan.2007.03.005

[89] Engels EA, Wu X, Gu J, Dong Q, Liu J, Spitz MR. Systematic evaluation of genetic variants in the inflammation pathway and risk of lung cancer. Cancer Res 2007; 67: 6520-27. http://dx.doi.org/10.1158/0008-5472.CAN-07-0370

[90] Son JW, Kang HK, Chae MH, Choi JE, Park JM, et al. Polymorphisms in the caspase-8 gene and the risk of lung cancer. Cancer Genetics Cytogenetics 2006; 169: 121-27. http://dx.doi.org/10.1016/j.cancergencyto.2006.04.001

[91] Yin J, Vogel U, Ma Y, Qi R, Sun Z, et al. DNA repair gene XRCC1 and genetic susceptibility of lung cancer in a northeastern Chinese population. Lung Cancer 2007; 56: 153-60. http://dx.doi.org/10.1016/j.lungcan.2006.12.012 
[92] Williams M, Sandler A. The epidemiology of lung cancer. Cancer Treat Res 2001; 105: 31-52.

http://dx.doi.org/10.1007/978-1-4615-1589-0 2

[93] Grant J. Proper use and recognized role of TPN in the cancer patient. Nutrition 1990; 6: 6s-7s.

[94] Bauer J, Capra S. Nutrition intervention improves outcomes in patients with cancer cachexia receiving chemotherapy: a pilot study. Support Care Cancer 2005; 13: 270-4. http://dx.doi.org/10.1007/s00520-004-0746-7

[95] McMahon K, Decker G, Ottery FD. Integrating proactive nutritional assessment in clinical practices to prevent complications and cost. Semin Oncol 1998; 25: 20-7.

[96] Bruera E. ABC of palliative care. Anorexia, cachexia, and nutrition. BMJ 1997; 315: 1219-22. http://dx.doi.org/10.1136/bmj.315.7117.1219

[97] Rivadeneira DE, Evoy D, Fahey TJ 3rd, Lieberman MD, Daly JM. Nutritional support of the cancer patient. CA Cancer J Clin 1998; 48: 69-80.

http://dx.doi.org/10.3322/canjclin.48.2.69

[98] American Cancer Society. Nutrition for the Person with Cancer: A Guide for Patients and Families. Atlanta, Ga: American Cancer Society, Inc., 2000.

[99] Shils M. Nutrition and Diet in Cancer Management. In: Shils ME, Olson JA, Shike M, et al. Eds. Modern Nutrition in Health and Disease. $9^{\text {th }}$ ed. Baltimore: Williams \& Wilkins 1999; pp. 1317-47.

[100] Laskin JJ, Sandler AB. First-line treatment for advanced nonsmall-cell lung cancer. Oncology 2005; 19: 1671-6.

[101] Breathnach OS, Freidlin B, Coley B, Green MR, Johnson DH, et al. Twenty-two years of Phase III trials for patients with advanced non-small cell lung cancer: sobering results. J Clin Oncol 2001; 19: 1734-42.

[102] Morgan G, Ward R, Barton M. The Contribution of Cytotoxic Chemotherapy to 5-year Survival in Adult Malignancies. Clin Onco 2004; 16: 549-60. http://dx.doi.org/10.1016/j.clon.2004.06.007

[103] Croswell JM, Baker SG, Marcus PM, Clapp JD, Kramer BS. Cumulative incidence of false-positive test results in lung cancer screening: a randomized trial. Ann Intern Med 2010; 152: 505-12.

[104] Humphrey LL, Teutsch S, Johnson M. U.S. Preventive Services Task Force. Lung cancer screening with sputum cytologic examination, chest radiography, and computed tomography: an update for the U.S. Preventive Services Task Force. Ann Intern Med 2004; 140: 740-53.

[105] Chan HP, Lewis C, Thomas PS. Exhaled breath analysis: novel approach for early detection of lung cancer. Lung Cancer 2009; 63: 164-8.

http://dx.doi.org/10.1016/j.lungcan.2008.05.020

[106] Kharitonov SA, Yates D, Robbins RA, Logan-Sinclair R, Shinebourne EA, et al. Increased nitric oxide in exhaled air of asthmatic patients. Lancet 1994; 343: 133-5. http://dx.doi.org/10.1016/S0140-6736(94)90931-8

[107] Liu J, Sandrini A, Thurston MC, Yates DH, Thomas PS. Nitric oxide and exhaled breath nitrite/nitrates in chronic obstructive pulmonary disease patients. Respiration 2007; 74: 617-23. http://dx.doi.org/10.1159/000106379

[108] Horvath I, Lazar Z, Gyulai N, Kollai M, Losonczy G. Exhaled biomarkers in lung cancer. Eur Respir J 2009; 34: 261-75. http://dx.doi.org/10.1183/09031936.00142508

[109] Vachani A, Nana-Sinkam P. Searching for the elusive biomarker in lung cancer. Where should we look? Cancer Biol Ther 2010; 10: 273-5. http://dx.doi.org/10.4161/cbt.10.3.12695

[110] NSCLC Meta-Analyses Collaborative Group. Chemotherapy in Addition to Supportive Care Improves Survival in Advanced Non-Small-Cell Lung Cancer: A Systematic Review and Meta-Analysis of Individual Patient Data From 16 Randomized Controlled Trials. J Clin Oncol 2008; 26: 4617-25.

http://dx.doi.org/10.1200/JCO.2008.17.7162

[111] Salgia R, Harpole D, Herndon JE 2nd, Pisick E, Elias A, Skarin AT. Role of serum tumor markers CA 125 and CEA in non-small cell lung cancer. Anticancer Res 2001; 21: 1241-6.

[112] McWilliams A, Lam B, Sutedja T. Early proximal lung cancer diagnosis and treatment. Eur Respir J 2009; 33: 656-65. http://dx.doi.org/10.1183/09031936.00124608

[113] Molina JR, Yang P, Cassivi SD, Schild SE, Adjei AA. Nonsmall cell lung cancer: epidemiology, risk factors, treatment, and survivorship. Mayo Clin Proc 2008; 83: 584-94.

[114] National Cancer Institute. Nutrition in Cancer Care. http://www.cancer.gov/cancertopics/pdq/supportivecare/nutrit ion. Accessed: 19 September, 2012.

[115] Langstein $\mathrm{H}$, Norton J. Mechanisms of cancer cachexia. Hematol Oncol Clin North Am 1991; 5: 103-23.

Received on 26-08-2012

Accepted on 24-11-2012

Published on 31-12-2012

\section{DOI: http://dx.doi.org/10.6000/1927-3037.2012.01.04.5}

(c) 2012 Steve Yap; Licensee Lifescience Global.

This is an open access article licensed under the terms of the Creative Commons Attribution Non-Commercial License (http://creativecommons.org/licenses/by-nc/3.0/) which permits unrestricted, non-commercial use, distribution and reproduction in any medium, provided the work is properly cited. 